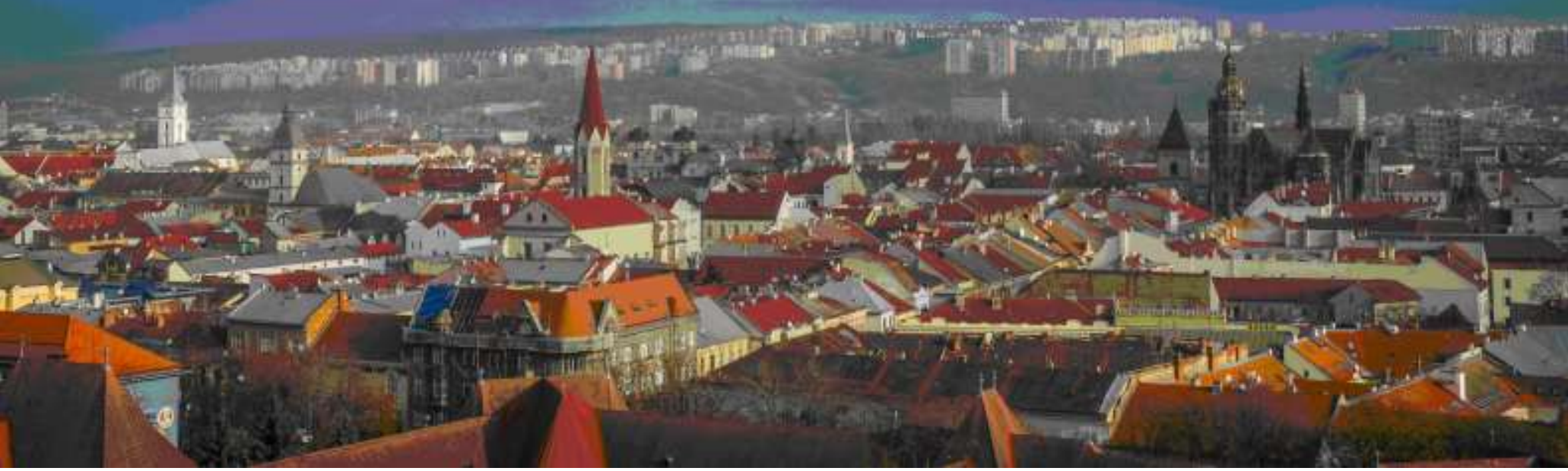

\title{
QUALITY AND LEADING INNOVATION
}

\section{International Scientific Conference}

\section{September 18 - 19, 2014}

\section{Introduction speeches}

Jozef Mihok - president of the Slovak Office of Standards, Metrology and Testing

Kristína Zgodavová - conference founder, Slovak Republic

Michal Tkáč - conference co-founder, dean of the Faculty of Business Economy with seat in Košice, EUBA Slovak Republic

Peter Horňak - dean of the Faculty of Metallurgy, TUKE, Slovak Republic

\section{Key note speeches}

Homo Digitalis, Lidmila Fusková, Czech Republic

Konis production data acquisition and management system in Faurecia Kosice, Lubomír Lengyel, Slovak Republic

Open innovation, quality and knowledge management, Paivi Haapalainen, Finland

Perfect Execution: Supply chain build to customer requirements, Milan Šesták, Slovak Republic

Research and innovation strategy for intelligent specialization of Slovak Republic in the context of technologies and their impact on quality in industry, Peter Magvaši, Slovak Republic

Smart Specialization within Regional Renewable Energy Innovations - Case: Ostrobothnia Region in Finland, Josu Takala, Finland

Sweeping Transformation of the Plant Vrchlabí ŠKODA Auto a.s., Ivan Slimak, Jr., Czech Republic

The fourth industrial revolution, Edgar Dietrich, Germany

Quality of life from the perspective of active aging and silver economy, Jozef Burian, Slovakia

\section{Honorary guests speeches}

Return to the roots of quality management, Alexander Linczényi, Slovak Republik

Paradigms, milestones, dominants and barriers of quality in Slovakia, Ivan Slimák, Sr., Slovak Republic

\section{Other announced speeches}

A generalization of traditional Kano model for customer requirements analysis, Renáta Turisová, Slovak Republic

Application of decision trees for nonconformity prediction of steel plates surface, Matúš Horváth, Slovak Republic 
Case study of balanced scorecard use in automotive industry, Anna Nagyová, Andrea Sütőová, Slovak Republic

Cluster potential in Slovak regions in context of business environment's quality, Viera Kuzmišinová, Peter Kuzmišin, Slovak Republic

Computer aided knowledge discovery and data mining, Renáta Janošcová, Slovak Republic Creativity and creative climate as a lever for innovation, Šárka Janků, Růžena Petř́ková, Czech Republic Design of experiment in truck company, Michal Tkáč, Jr., Slovak Republic

Development of region by utilization of geothermal power plant, Michal Cehlár, Zuzana Jurkasová, Slovak Republic

Dimensional verification of implants make by additive manufacturing technologies, Teodor Tóth, Radovan Hudák, Jozef Živčák, Slovak Republic

Economic indicators of quality and their influence to cost effectiveness, Katarína Teplická, Marcela Pavlíčková, Slovak Republic

Fault Tree Analysis for Brinell hardness measurement method, Jozef Petrík, Peter Blaško, Slovak Republic

Fighting noise is a long distance run, Peter Weiss, Vojtech Mikloš, Slovak Republic

Full commitment of top management in Macedonian high education institutions, Nako Taskov, Elizabeta Mitreva, Julijana Sazdova, Nikola Dimitrov, Dejan Metodijeski, Republic of Macedonia

GAP analysis of approaches to implementation of management systems, Miroslav Hrnčiar, Slovak Republic

Implementation and certification the quality management system in university, Jozef Habánik, Jaroslav Jambor, Slovak Republic

Implementation of IMS: A Costs Model, Anna Moščáková, Slovak Republic

Innovations through VDL model, Pavel Mikuš

Integrated assessment of buildings quality in the context of sustainable development principles, Mária Kozlovská, Zuzana Struková, Alena Tažiková, Slovak Republic

Integrated cost model for improving the production in companies, Zuzana Hajduová, Slovak Republic

Lesson learned from using interactive training software for Statistical Process Control, Peter Bober, Slovak Republic

Modelling of innovative projects funding SMEs in Slovakia in Horizon 2020, Milan Majerník, Lubica Lešková, Juraj Čorba, Alexander Tarča, Slovak Republic

Modelling of integrated energy management in companies, Milan Majerník, Martin Bosák, Lenka Štofová, Petra Szaraszyová, Slovak Republic

Open Innovation and it utilisation in education, Iveta Korobaničová, Slovak Republic

Playing, doing, thinking, learning: Experiences from the applications of the quality management system role play simulation at the university courses, Kristína Zgodavová ${ }^{1}$, Matúš Horváth ${ }^{1}$, Pavol Palfy ${ }^{1}$, Lubomír

Lengyel $^{1}$, Rozmarína Dubovská ${ }^{2}$ Paivi Haappalainen ${ }^{3}$, Aleš Bourek ${ }^{2}$, Slovak Republic ${ }^{1}$, Czech Republic ${ }^{2}$, Finland $^{3}$

Position of the Slovak Republic in the European Union from the perspective of the Europe 2020 objectives, Emília Spišáková, Slovak Republic

Prediction of demand for primary bond offerings using artificial neural networks, Róbert Verner, Michal Tkáč, Sr., Slovak Republic

Support of innovation and SMEs quality as part of SMART policy of region, Renáta Nováková, Slovak Republic

Sustainability of digital public spaces, Matej Hudák, Slovak Republic

The effect of employee training and participation on customer satisfaction, Zulnaidi Yaacob, Malaysia 
The impact of product innovation on relationship quality: Empirical evidence from Malaysia, Jalal Hanaysha, Haim Hilman, Noor Hasmini Abd. Ghani, Malaysia

Using VDL model for innovation, Pavel Mikuš, Slovak Republic

Utilization of selected innovative management methods and tools in local self government. Ondrej

Železník, Soňa Hurná, Slovak Republic

Programme

\begin{tabular}{|c|c|}
\hline \multicolumn{2}{|c|}{ September 18, 2014 } \\
\hline $10: 00-13: 00$ & Registration \\
\hline $13: 00-13: 30$ & Conference opening \\
\hline $13: 30-17: 00$ & Plenary section - Aula maxima \\
\hline & $\begin{array}{r}\text { Key note speakers } \\
\text { Jozef Burian; Edgar Dietrich; Lidmila Fusková; Paivi Haappalainen; Lubomír Lengyel; } \\
\text { Peter Magvaši; Ivan Slimák, Jr.; Milan Šesták; Josu Takala }\end{array}$ \\
\hline Plenary section chair & Pavol Palfy \\
\hline $17: 00-17: 30$ & Coffee break \\
\hline $17: 30-19: 00$ & Panel discussion and Guitar concert \\
\hline
\end{tabular}

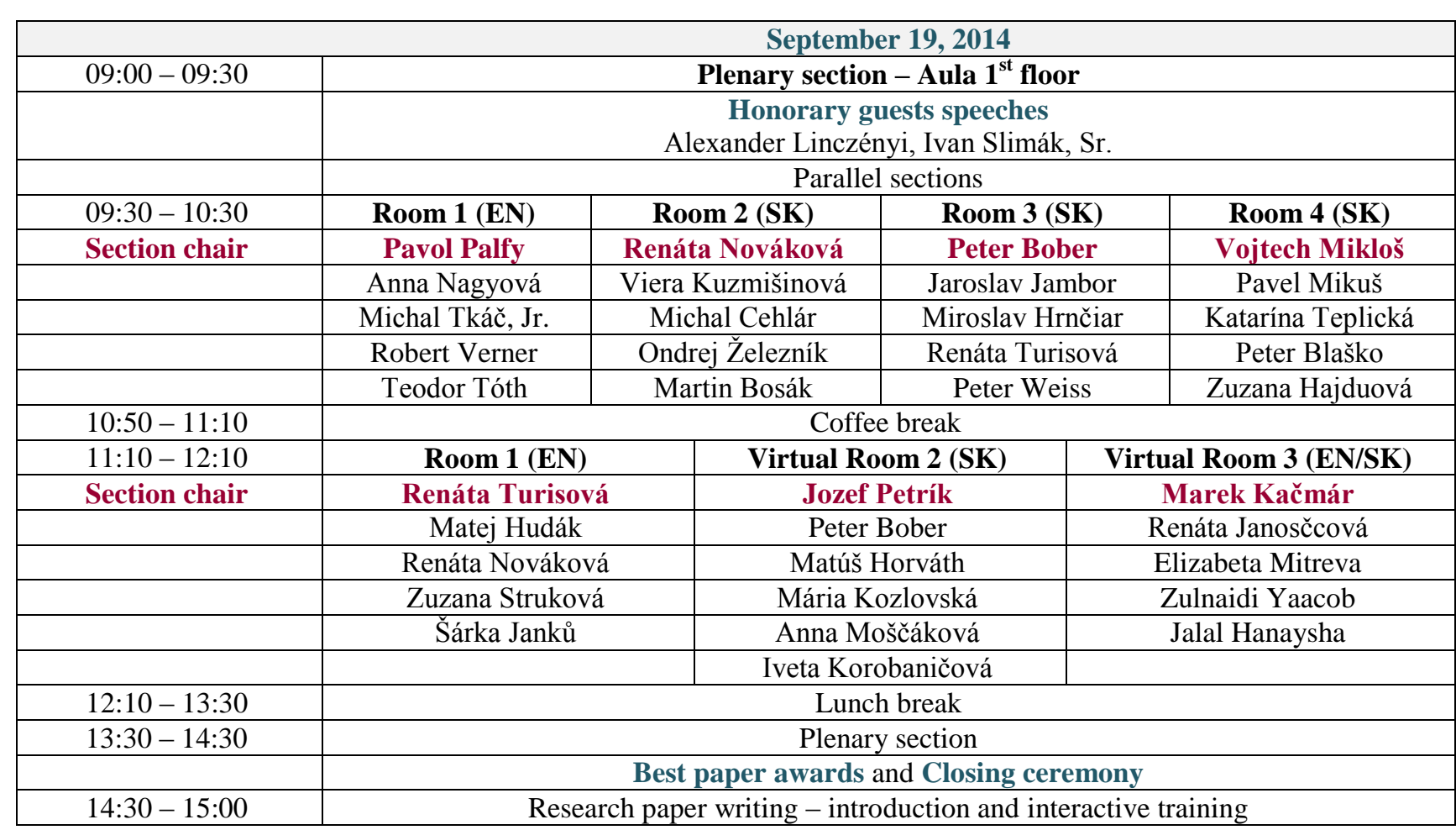




\section{Logistics and map}

Košice city centre, Moyzesova 64 (direct), or Tajovského 13 (please ring), Timonova (by car)

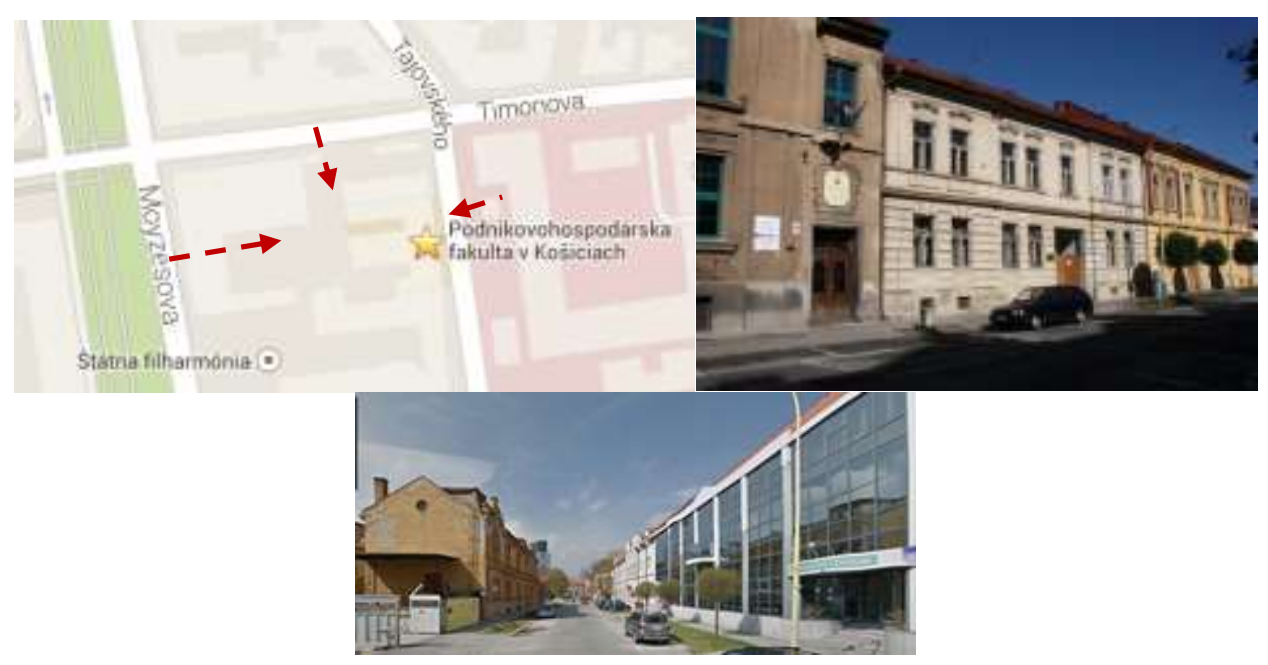

\section{Supporting projects}

University of Economics, Faculty of Business Economy with seat in Košice
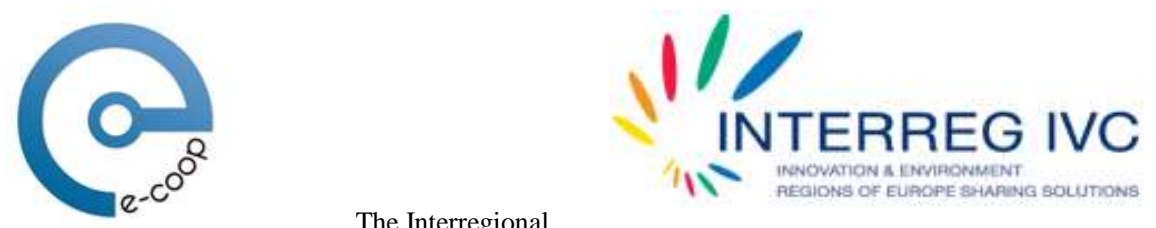

The Interregional

Cooperation Programme

INTERREG IVC, financed by the European Union's Regional Development Fund, helps Regions of

Europe work together to share experience and good practice in the areas of innovation, the knowledge economy, the environment and risk prevention.

\section{Technical University of Košice, Faculty of Metallurgy}

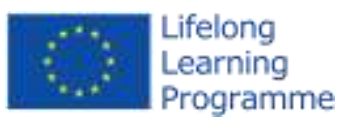

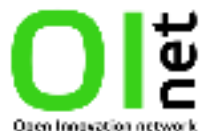

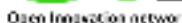

European Academic Network for Open Innovation OI-Net 542203-LLP-1-2013-1-FI ERASMUS-ENW

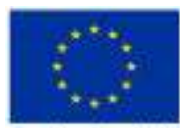

Európska únia

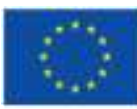

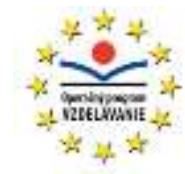

Lifelong Learning Programme
OP Vzdelávanie (ESF) ITMS 26110230070 Balík inovatívnych prvkov pre skvalitnenie a inovácie vzdelávania na TUKE

Leonardo da Vinci project SK 126651BB52FF2AA1 "Guiding the Patients' Relatives with the Help of Illness Management Handbook Including the 50 Most Common Illnesses" 


\title{
FULL COMMITMENT OF TOP MANAGEMENT IN MACEDONIAN HIGH EDUCATION INSTITUTIONS
}

\author{
DOI: 10.12776/QALI.V1.\#2
}

\author{
NAKO TASKOV, ELIZABETA MITREVA, JULIJANA SADZOVA, \\ NIKOLA DIMITROV, DEJAN METODIJESKI
}

\begin{abstract}
Purpose: This paper presents an analysis regarding the condition of Macedonian higher education institutions through one of the criteria for receiving a European Quality Award in the direction of the activities undertaken in relation to achieve the planned satisfaction of all those who have financial interest in it.
\end{abstract}

Methodology: The research is designed as an attempt to depict the existing condition within Ten Macedonian higher education institutions regarding quality system design and implementation, analyzed through 4 polls in the "house of quality" who's top is the ultimate management, and as its base measurement, evaluation, analyzing and comparison of the quality are used. A special attention has been given to the gathering of the entering data included in the research. As an instrument, there was a questionnaire used that was designed to give an accurate analysis in a manner of complete and correct fulfilling.

Findings: Although the philosophy of total quality management (TQM) is deeply involved in many higher education institutions and business aspects of European and other countries, it is not sufficiently present in the country and other developing countries. In this paper we make an effort to, using the principles of TQM, develop a universal, integrated methodology for design and implementation of TQM system in higher education.

Practical implications: This methodology should help to give useful guidance to all higher education institutions tend to be educational institutions "world class". The model - methodology proposed is an integral and universal meaning that it is applicable to all higher education institutions, regardless of their nature, and the success of its application depends if it is only achieved integration of information technology with the internal standardization, methods and techniques for 
PROCEEDINGS OF THE SCIENTIFIC CONFERENCE QUALITY AND LEADING INNOVATION'2014 KoŠICE - HrADEC KRÁLOVÉ, SEPTEMBER 19-20, 2014

improving quality, system cost analysis, but with continuing education and motivation of employees.

Keywords: higher education; leadership; methodology; quality system; TQM strategy.

\section{INTRODUCTION}

National Programme for the Development of Education in Macedonia (www.npro.edu.mk) expresses the desire of the state to bring about change in education that will enable compatibility of study programs, recognition and recognition of degrees awarded at all levels of education in European educational space and greater employability in the European labour market. The structure of the system of quality assurance in higher education institutions correspond to regulation, although there is a deep gap between management of quality and culture of quality. Higher education institutions are aware of the need to redesign the profile and curriculum and quality of teaching depends primarily responsible for the reassessment of values, attractiveness of an innovative learning environment, and in the highest degree will depend on the leadership of higher education institutions. Macedonian higher education institutions should accept new TQM strategy and implement it in educational processes.

\section{The essence of TQM (Total Quality Management) strategy}

TQM philosophy is embodied in many higher education institutions in the world, and its application means new key change in the approach to the quality of the educational process, according to Kano (1996). The first change concerns the establishment of a process of continuous improvement in all segments of higher education institutions with the involvement of academic staff, and the other, to meet the needs of all users (students, teachers, Ministry of Education, employment and professional bodies, society general and international forum) with the results of the institution.

\section{Factors for successful implementation of TQM strategy in higher education institutions}

A condition for successful implementation of TQM strategy in higher education institutions is having modern management, particularly strong leadership (according Ciampa, 2005). Leadership Initiative includes the top, commitment to TQM philosophy with their active participation, according to academics, penetration of opinions, proactive work style, teamwork, training, support for successful actions and achievements. Spreading the TQM conception in higher education institutions requires a particular social and cultural level of the middle (habits and mentality of employees), infrastructure creation and development of corporate culture in higher education institutions. In this paper we make an effort 
to, using the principles of TQM, develop a universal, integrated methodology for design and implementation of TQM system in higher education Mitreva (2010). This methodology should help to give useful guidance to all higher education institutions tend to be educational institutions "world class".

\section{METHODOLOGY}

The research is designed as an attempt to depict the existing condition within Ten Macedonian higher education institutions regarding quality system design and implementation, analyzed through 4 polls in the "house of quality" who's top is the ultimate management, and as its base measurement, evaluation, analyzing and comparison of the quality are used.

\subsection{Objectives of the research}

This paper presents an analysis regarding the condition of Macedonian higher education institutions through one of the criteria for receiving a European Quality Award in the direction of the activities undertaken in relation to achieve the planned satisfaction of all those who have financial interest in it (Mitreva, 2010).

\subsection{Description of the instrument}

A special attention has been given to the gathering of the entering data included in the research. As an instrument, there was a questionnaire used that was designed to give an accurate analysis in a manner of complete and correct fulfilling. At the same time, there were some direct contacts made with the top management and the employees in order to depict the authenticity of the questionnaire and to present the realistic condition of the Macedonian higher education institutions. The data received from the research are processed with an adequate mathematical - statistical methods. In this regard, the Pareto analysis was used for frequency as well as for analysis in order to calculate the involvement of certain answers in percentages.

\subsection{Analysis and discussion of results}

The usage of the internal standardization and quality providing within Macedonian higher education institutions

If the quality system is introduced and certified according the ISO 9001:2008 standard, it means that the higher education institutions will be aware about the values of quality and will be able to operate with it. There is a stiff determination of the top management regarding quality; also there is a defining and organizational culture, documentation for the system and trained individuals as well.

The alerting fact is that only $40 \%$ of the examined Macedonian higher education institutions (10) owe a quality system according ISO 9001:2008, which appears as a relatively small figure. The need of training according international 
PROCEEDINGS OF THE SCIENTIFIC CONFERENCE QUALITY AND LEADING INNOVATION'2014 KoŠICE - HrADEC KRÁLOVÉ, SEPTEMBER 19-20, 2014

standards has forced some of the top managers to implement a quality system. The structure of the higher education institutions that have certified a quality system according ISO 9001:2008 and the assets from its implementation is seen through the following:

- $60 \%$ of the Macedonian higher education institutions that have implemented the quality system, see the assets in gaining a better quality of the services, reduction of the total costs, consumers' contentment etc.

- $20 \%$ of the examined aim to get ISO certificate hanging on the wall, without real purpose to improve the higher education institutions, to manufacture quality services, and to settle the business processes for a cooperation with the buyers and partners worldwide;

- $20 \%$ of the examined that have implemented the quality providing system of services but considered that only serve to realize additional unnecessary expenses and bureaucracy, do not see assets, do not realize the desired advantages on the market, and do not fulfil the demands of ISO 9001 standards.

\section{The usage of quality methods and techniques within Macedonian higher education institutions}

Quality providing methods and techniques are instruments for implementing actions in order to improve quality. Those are integral part of quality management according a defined policy, aims and responsibilities of the higher education institutions, as well as creating comparative advantages on the market. In order to find out if the Macedonian higher education institutions have established a control of processes by achieving defined quality with least costs of working, the question is raised: what type of quality control of services do they practice?

- $60 \%$ of the Macedonian higher education institutions have claimed that they possess quality control;

- $30 \%$ of them practice $100 \%$ control;

- $10 \%$ implement statistical control.

The quality as a phenomenon within the Macedonian higher education institutions is at a lowest level because of the bad managing of the business processes, inefficient control, and huge percentage of complaints, which exceeds the permitted one. The reasons are not the deficiencies of modern technology but weak managerial abilities, qualifications and completeness and qualitative leading of business processes.

\section{Do Macedonian companies learn new things?}

In order to get the real picture of the Macedonian higher education institutions, whether they learn and whether they stimulate the individual and collective 
PROCEEDINGS OF THE SCIENTIFIC CONFERENCE QUALITY AND LEADING INNOVATION'2014 KoŠICE - Hradec KRÁLOVÉ, SEPTEMBER 19-20, 2014

education in order to improve the outcomes of the organization in a way that is important for all users, there are few questions raised: do those higher education institutions gain additional knowledge?

- $60 \%$ of them practice training from time to time at work;

- $20 \%$ of them do not practice trainings for gaining additional knowledge;

- only $20 \%$ of them have attended a training twice a year that is a minimum of a yearly professional improvement in the era of education.

The alarming is the fact that $20 \%$ higher education institutions do not practice training for gaining additional knowledge and a lifelong improvement is the condition for survival on the modern business. Those real indicators show that not attending training on a regular basis is one of the reasons for being uncompetitive at the global market.

\section{How much is the motivation a significant factor for quality providing?}

The motivation of the employees is the most sensitive part of the organizational behavior and is expressed through contentment of the employees. The question how do the companies motivate the employees, the answer that appears most frequently is the increase of payment:

- $70 \%$ of the examined have responded that they motivate employees through salary raise;

- $10 \%$ of them motivate the employees by bonuses apart from the salary raise;

- $10 \%$ of them do it by allowing a development to a higher valued position in the higher education institutions;

- $10 \%$ of them motivate the employees using combined and complex methods that are known and accessible to all employees.

The necessity to build a solid system of quality and usage of TQM strategy within Macedonian higher education institutions would be realized only by building a system for motivation as a consisting part of the house of quality, and this refers to: integrity of motivation factors, as measure for stimulation and strategies that will systematically and planned incorporate within the working and organizational activities, in order to motivate the employees. But in order to achieve that, the top management needs to:

- attract and maintain the most quality personnel;

- provide a quality realization of the undertaken tasks;

- stimulate creativity and innovativeness; 
PROCEEDINGS OF THE SCIENTIFIC CONFERENCE QUALITY AND LEADING INNOVATION'2014 KoŠICE - HrADEC KRÁLOVÉ, SEPTEMBER 19-20, 2014

- provide an identification of the employees with the higher education institution and their engagement in its constant development.

\section{How to manage the quality costs within Macedonian higher education institutions?}

Quality costs appear because of existence or a possibility of a bad quality. The question whether Macedonian higher education institutions make analysis for quality costs (complains, reclamations, discarded products etc), the gained results refer to the following:

- $30 \%$ of them make analysis of costs in terms of quality;

- $70 \%$ of them set the analysis to a checkup of complains of consumers, without analysis of the discarded, no checkup of its origin and reasons.

All of this leads to a major loss, not realizing of planned financial outcome, loss of respect, loss of additional time and material for corrections.

The practice within Macedonian higher education institutions refers to the fact that they do not pay attention to the analysis of costs for quality because of their lack of knowledge therefore the services are not competitive enough at the market. In this paper we make an effort to, using the principles of TQM, develop a universal, integrated methodology for design and implementation of TQM system in higher education, Mitreva (2010). This methodology should help to give useful guidance to all higher education institutions tend to be educational institutions "world class".

\section{INTEGRAL METHODOLOGY FOR DESIGNING AND IMPLEMENTING TQM SYSTEM IN MACEDONIAN HIGHER EDUCATION INSTITUTIONS}

The need of redesign or reengineering can occur in educational institutions who want to leave the traditional approach by introducing a new, modern approach to education and science. Both approaches are based on the same tenets: competence, ability and knowledge, but they are applied differently according to the country's technological development and higher education systems therein.

Although the philosophy of total quality management (TQM) is deeply involved in many higher education institutions and business aspects of European and other countries, it is not sufficiently present in the country and other developing countries. Especially critical is the long term point of this philosophy, when results do not come "overnight". Globalization allows creating a European area of higher education in order to facilitate joint knowledge creation and greater mobility of students and academic staff. Thus Europe has become a common 
space of higher education, the rules and principles designed to work together and to use the common results.

In this paper is given integral methodology for the design of TQM (Total Quality Management) system in higher education institutions and its implementation in practice of higher education, as well as actions to be taken to build a system of quality assurance. The success of the application of TQM strategy depends on the commitment of the academic staff and administration and their motivation.

Integral methodology for designing and implementing TQM system, as suggested in this paper, consists of more methodologies Mitreva (2010): Methodology for subsystem-internal standardization; Methodology for subsystem-Statistical Process Control (SPC); Methodology for analysis of total cost of a given process; Methodology for subsystem-education; Methodology about evaluating the success of the designed and implemented system in TQM (Audit). Basis in creating this model is redesign, after that, it starts a new phase of business-continuous improvement, or turning round Deming quality (Plan-DoCheck-Act). 
PROCEEDINGS OF THE SCIENTIFIC CONFERENCE QUALITY AND LEADING INNOVATION'2014 KoŠICE - HrADEC KRÁLOVÉ, SEPTEMBER 19-20, 2014

\subsection{Methodology for subsystem - internal standardization}

Each institution builds its own quality assurance system in accordance with the teaching - educational field that nurtures and under the conditions in which it is performed, and within the European standards for higher education. Working under the acts that defines all procedures of teaching - educational and scientific research and obligations and responsibilities of all employees. The development flow of the design and implementation process of internal standardization is carried out through the following activities (See Figure 1).

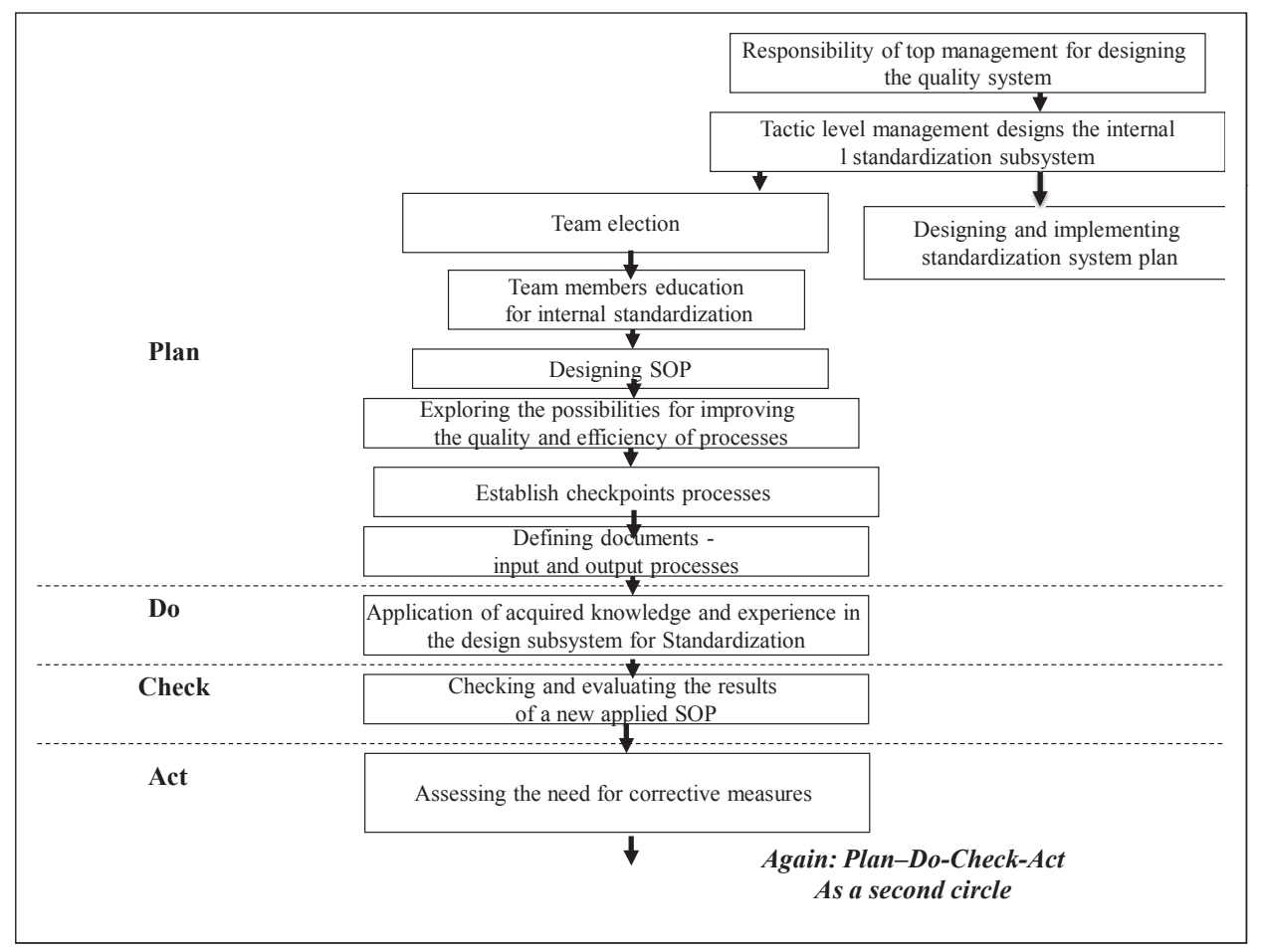

Figure 1 - Flow of process design and implementation of the subsystem of internal standardization

Checking (assessment) is organized within the institution (self-evaluation) and out of the institution by the Agency for evaluation. 
PROCEEDINGS OF THE SCIENTIFIC CONFERENCE QUALITY AND LEADING INNOVATION'2014 KoŠICE - HrADEC KRÁLOVÉ, SEPTEMBER 19-20, 2014

\subsection{Methodology for subsystem - Statistical Process Control (SPC)}

Measuring the quality of the educational process is carried out by applying appropriate methods and techniques, which provide data collection and information about the current situation. Based on the data and information evaluated basic level indicators work and selected problems that require special attention. The ongoing construction of the subsystem of statistical process control is carried out through the following activities (See Figure 2).

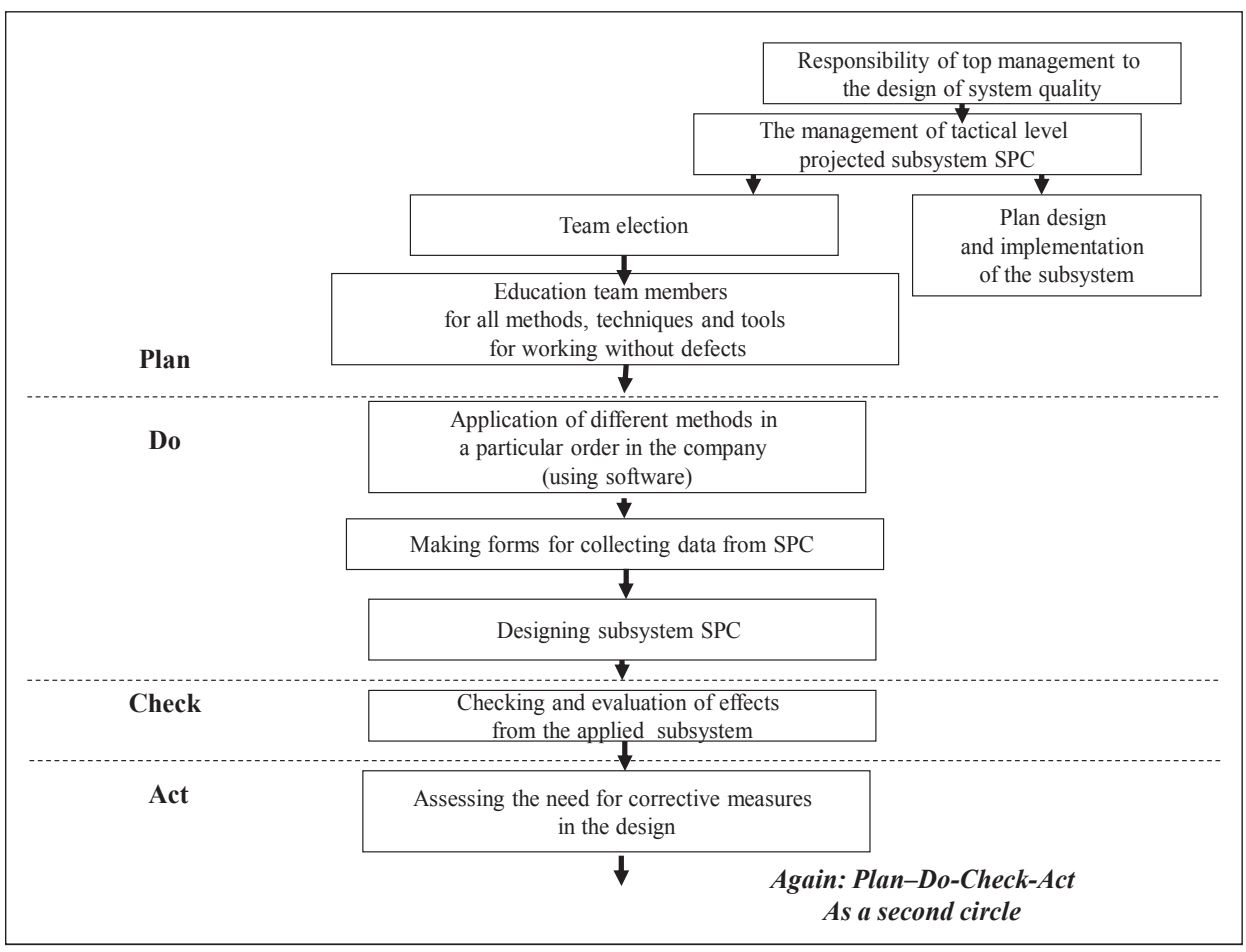

Figure 2 - Flow of the process of designing the subsystem SPC 
PROCEEDINGS OF THE SCIENTIFIC CONFERENCE QUALITY AND LEADING INNOVATION'2014

KOŠICE - HRADEC KRÁLOVÉ, SEPTEMBER 19-20, 2014

\subsection{Methodology for analysis of total cost of a given process}

TQM strategy requires quality management processes, and management costs. The methodology of the cost can be used for any process in the higher education institution (see Figure 3).

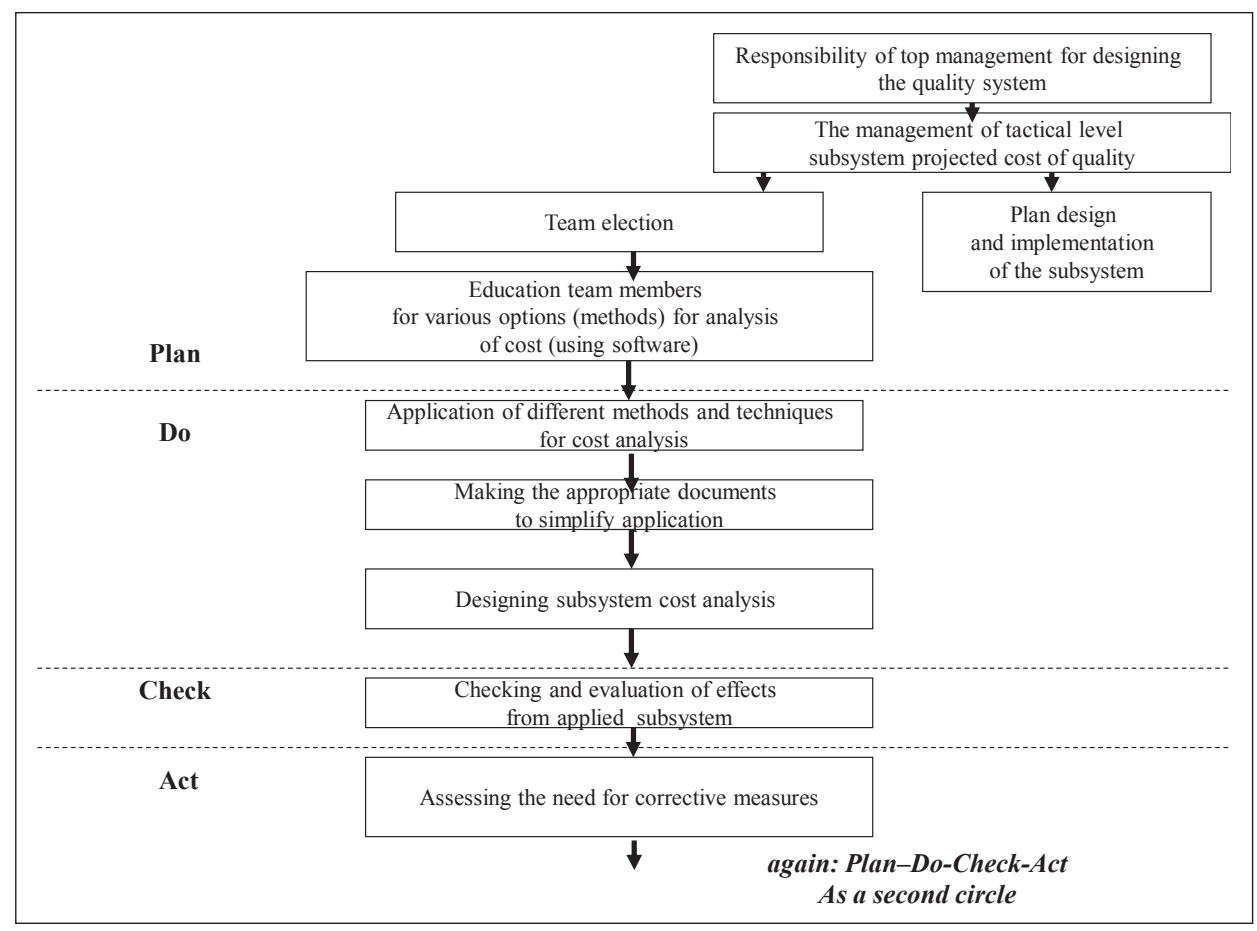

Figure 3 - Flow of the process of designing the subsystem of costs 
PROCEEDINGS OF THE SCIENTIFIC CONFERENCE QUALITY AND LEADING INNOVATION'2014

KOŠICE - HRADEC KRÁLOVÉ, SEPTEMBER 19-20, 2014

\subsection{Methodology for subsystem - Education}

The system providing total quality management should not only be designed well but it is necessary its consistent implementation in practice. It is therefore necessary continuing education, training, management and academic staff, training of students and the administration and application of Deming circle of quality (See Figure 4).

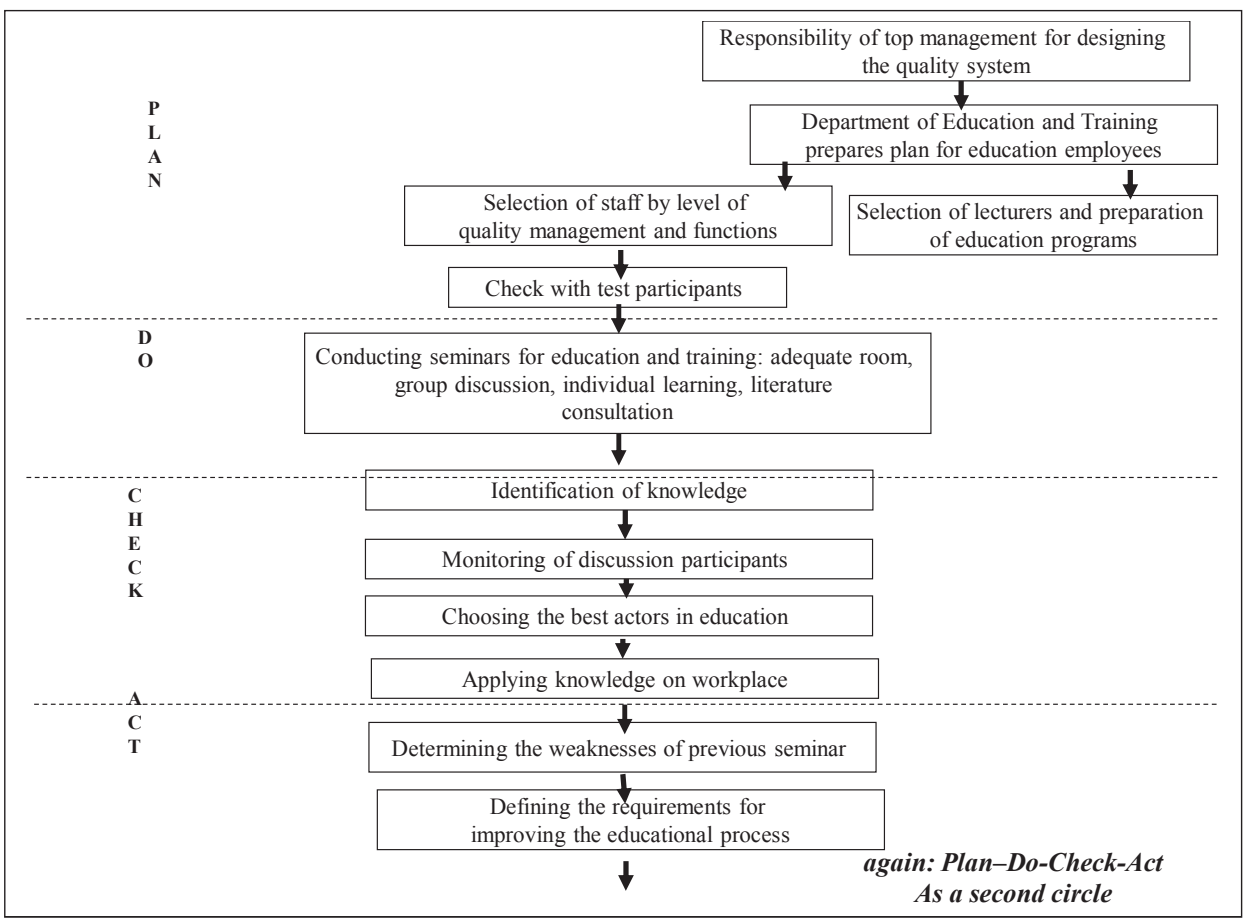

Figure 4-Flow of the process of design and implementation of the subsystem of education 
PROCEEDINGS OF THE SCIENTIFIC CONFERENCE QUALITY AND LEADING INNOVATION'2014

KoŠICE - HrADEC KRÁLOVÉ, SEPTEMBER 19-20, 2014

\subsection{Methodology for evaluating the results of the implemented system and projected on TQM (Audit)}

The purpose of the fifth stage - control is the assessment and monitoring of the results of previous stages (see Figure 5).

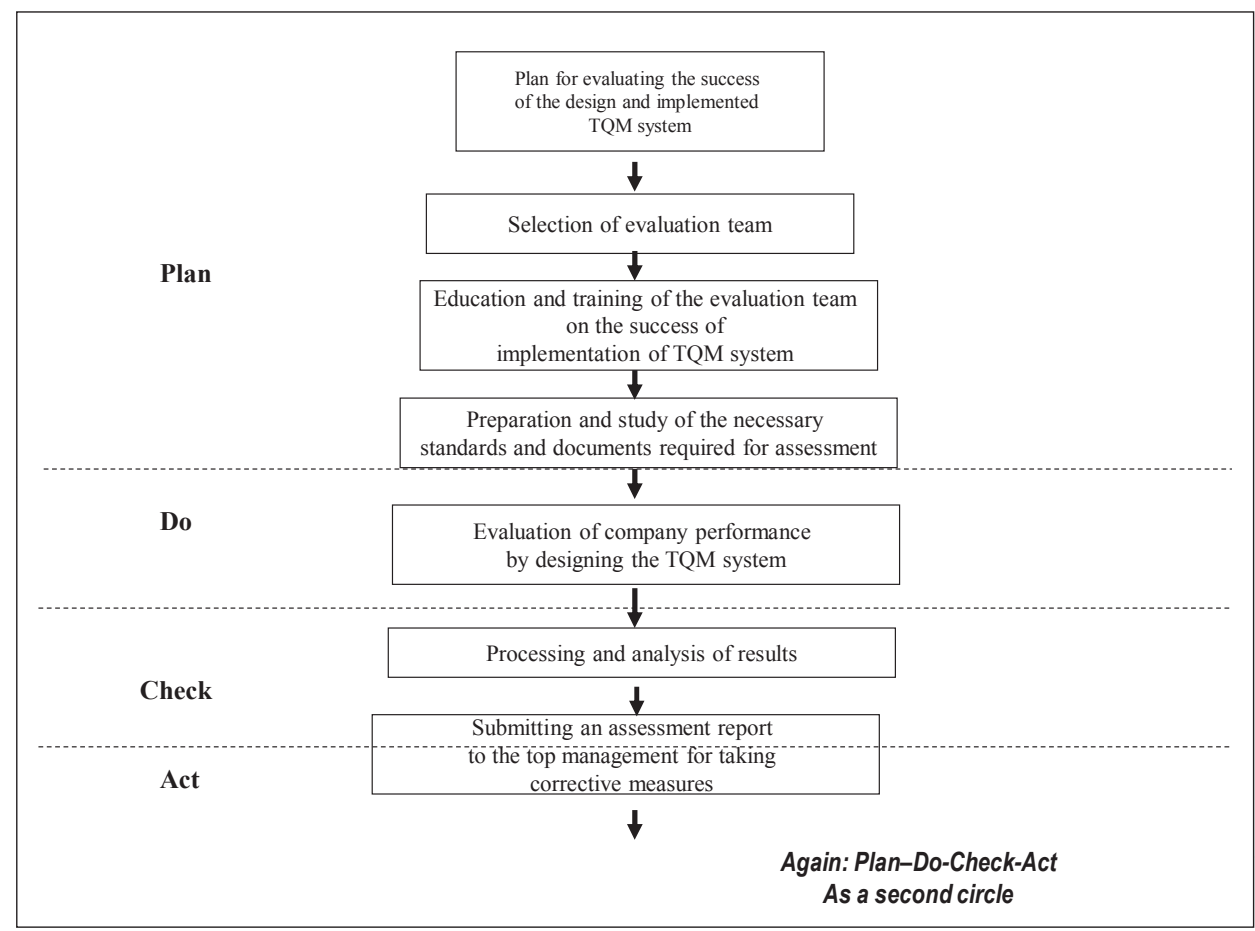

Figure 5 - Flow process for evaluating the success of the designed and implemented system in TQM

At this stage of verifying and modifying the system to create new rules, procedures, instructions to staff and other norms of operation.

\section{CONCLUSION}

The model - methodology proposed by (Mitreva 2010) is an integral and universal meaning that it is applicable to all higher education institutions, regardless of their nature, and the success of its application depends if it is only achieved integration of information technology with the internal standardization, methods and techniques for improving quality, system cost analysis, but with continuing education and motivation of employees. 
PROCEEDINGS OF THE SCIENTIFIC CONFERENCE QUALITY AND LEADING INNOVATION'2014 KoŠICE - HrADEC KRÁlOVÉ, SEPTEMBER 19 - 20, 2014

Integral methodology for designing and implementing TQM system has feedback as a result of the necessity of ongoing improvement of educational processes. By repeating or spiral repetition of such cycles will see the benefits of the application by changing the organizational culture to such initiatives and an incentive to higher goals of excellence.

This methodology not only a success in the implementation of the improvement of educational processes in Macedonian higher education institutions, but to raise awareness of the academic staff and administration for their quality and focus on increasing the satisfaction of students, teachers, Ministry of Education and Science the employment and professional bodies, society in general and international forum. But without the support of leadership and without the involvement of academic staff, all efforts to improve will be in vain.

\section{Benefits of the proposal - the methodology for designing and implementing TQM system in higher education institutions}

Benefits of the methodology for designing and implementing TQM in higher education system are:

- the application of internal standardization improves responsibility of academic staff in the implementation and administration of the educational process;

- the application of statistical methods and techniques to ensure the quality of education;

- application software packages increases performance in the application of statistical methods and techniques;

- by analyzing the cost of quality can be controlled losses and to reduce them to the minimum.

Besides these other important effects are expected to be achieved, such as:

- involvement of all employees in achieving the quality of the educational process;

- employee commitment to improving the quality of education;

- full commitment of top management to the system in TQM and its continuous improvement;

- ability to solve problems at all levels;

- small but significant improvements in educational processes and services;

- optimization of the educational process;

- disposing responsibility for decision-making at lower levels. 
PROCEEDINGS OF THE SCIENTIFIC CONFERENCE QUALITY AND LEADING INNOVATION'2014 KoŠICE - HrADEC KRÁLOVÉ, SEPTEMBER 19-20, 2014

Without the commitment of top management to set goals for the quality of the educational process and consistency in their implementation, these efforts will only be spending time and money, while at the same time will reduce the possibility of following such a successful initiative.

It should be emphasized that the benefits of the introduction of this model are not seen immediately, but in the long run. But it should not be a reason for the initial failure of the initiative, because quality is a long term process.

The benefits of implementing this model not only increase the commitment of top management and academic staff to improve the educational process, but achieving satisfaction of students, parents, teachers and society, we will continue to serve as the driving force for continuous improvement.

However, the conclusion remains that there is a clear determination of the Macedonian higher education institutions for the care and responsibility for ensuring and improving the quality of education, and thus increased the interest for cooperation with universities in the country, the region and Europe.

\section{REFERENCES}

Ciampa, D., (2005). Almost Ready: How Leaders Move Up, Harvard Business Review 83, No.1.

Chepjunoska, V., Donevski, B., (2005). Quality Assurance in Higher Education A view from Macedonia, Skopje - Bitola, pp. 39-150.

EFQM, (1992). Total Quality Management: The European Model for SelfAppraisal, European Foundation for Quality Management.

Harung, H.S., (1996). A world-leading learning organization: A case study of Tomra Systems, Oslo, Norway. The Learning Organization: an International Journal, Vol. 3, No. 4, pp. 22-34.

Kano, N., (1996). Business Strategies for the $21^{\text {st }}$ Century and Attractive Quality Creation, ICQ, Yokohama, pp.105.

Mitreva, E., (2011). Model-integral methodology for successful designing and implementing of TQM system in Macedonian companies. International Journal for Quality Research, Vol. 5, No. 4, pp. 255-260.

NPRO, 2013. National Programme for Development of Education 2005-2015, (2006), http://www.npro.edu.mk/, 12.08.2013.

Mitreva, E., Prodanovska V., (2013). The Management Teams are a Unique Business Potential that can Initiate, Identify and Manage Change within the 
PROCEEDINGS OF THE SCIENTIFIC CONFERENCE QUALITY AND LEADING INNOVATION'2014 KoŠICE - HRADEC KRÁlOVÉ, SEPTEMBER 19 - 20, 2014

Organization. In: Applied Social Sciences: Administration and Management. Cambridge Scholars Publishing, Newcastle upon Tyne, UK, pp. 57-65.

Prodanovska, V., Mitreva, E., (2012). Incorporation, authorization and encouragement of the employees in order to improve the quality of the educational process. In: Two decades of academic teaching, 18-19 June; Timișoara.

Beardwell, I., Holden, L., Claydon, T., (2004). Human Resource Management; A Contemporary Approach, Prentice Hall, Fourth Edition, pp. 124-387.

Ishikawa, K., (1995). President Touka Henkau Sozo Gakkai, "Thoughts on risk management "Creativity and risk management", JUSE, Societas Qualitatis, Vol. 9, No. 3, July/Aug, 5.

Juran, J. M., (1988). Juran on Planning for Quality, Free Press, New York, NY.

Mitreva, E., Jakovlev, Z., Koteski, C., Kitanov, V., Angelkova, T., (2012). Analysis of the existing management system in Macedonian companies and the necessity of accepting the TQM philosophy, International Journal of Pure and Applied Sciences and Technology, Vol. 8, pp. 54-63.

Woodall, J., Winstanley, D., (1998). Management development: Purposes, processes and prerequisites. In Management development: Strategy and practice, Oxford: Blackwell, pp. 3-17.

\section{ABOUT AUTHORS}

Prof. Nako Taskov, PhD, Faculty of Tourism and Business Logistics, University "Goce Delcev" - Stip, Macedonia, e-mail: nako.taskov@ugd.edu.mk

Assoc. Prof. Elizabeta Mitreva, PhD, Faculty of Tourism and Business Logistics, University "Goce Delcev" - Stip, Macedonia, e-mail: elizabeta.mitreva@ugd.edu.mk (corresponding author)

Julijana Sazdova, teacher at SOU Kole Nehtenin, Shtip, e-mail: j.sazdova@kolenehtenin.edu.mk.

Prof. Nikola Dimitrov, PhD, Faculty of Tourism and Business Logistics, University "Goce Delcev" - Stip, Macedonia, e-mail: nikola.dimitrov@ugd.edu.mk

Assoc. Prof. Dejan Metodijeski, PhD, Faculty of Tourism and Business Logistics, University "Goce Delcev" - Stip, Macedonia, e-mail: dejan.metodijeski@ugd.edu.mk 